\title{
Peranan Berbagai Pola Agroforestri Terhadap Tingkat Resiliensi Petani Di SUB DAS Minraleng Hulu
}

\author{
A. Azhar Armas ${ }^{1 *}$, Muh. Dassir1, Syamsuddin Millang1 \\ 1 Fakultas Kehutanan, Universitas Hasanuddin, Makassar \\ *Email: andi.azhar.armas@gmail.com
}

\begin{abstract}
This research wants to see the roles of various agroforestry patterns and the level of resilience of farmers in facing crisis/ekstreme conditions and how it affects farmers household income. This study aims to (1) describe the patterns of agroforestry applied by farmers, (2) Determine factors that influence resilience, (3) Analyze the level of resilience in various agroforestry patterns in the Upper Minraleng Upper watershed. Qualitative and quantitative analysis ware carried out on farmers in various agroforestry patterns and supported by research respondent information for each agroforestry pattern, 30 respondents were selected so that the total of respondens was 90 farmer household respondents. The results of the study shows that the agroforestry pattern applied by farmers in the Upper Minraleng Subwatershed is dominanted by teak, candlenut and acacia agroforestry patterns, in which all three patterns are managed in the form of agrisilviculture. Factors affecting resilience in various agroforestry patterns of farmers are the time of recovery at a critical time and the level of adaptation at a critical time. In addition, the highest resilience level is candlenutdominanted agroforestry pattern farmers with a total score of 1970, moderate resilience level in teak-dominanted agroforestry patterns with a total score of 1844 and the lowest agroforestry level in teak dominated agroforestry patterns with a total score of 1634 .
\end{abstract}

Keywords: Agroforestry, Resilience, Resilience of Level DOI: 10.24259/jhm.v12i2.9211

\section{PENDAHULUAN}

Di berbagai tempat di Indonesia, sistem agroforestri telah banyak diterapkan dengan berbagai pola tanam yang dikehendaki. Agroforestri merupakan salah satu sistem pengelolahan lahan yang telah dipraktekkan oleh petani dalam berbagai bentuk tergantung pada kondisi biofisik, sosial ekonomi dan budaya masyarakat. Sistem agroforestri telah banyak diterapkan oleh petani di berbagai tempat di Indonesia, salah satu daerah yang menerapkan sistem agroforestri adalah masyarakat Desa-Desa di Sub DAS Minraleng hulu dimana sebagian besar menggantungkan hidupnya pada lahan agroforestri untuk bertahan hidup.

Agroforestri dalam pelaksanaannya tidak jarang mengalami kegagalan, karena pengelolaannya yang kurang tepat. Penerapan sistem agroforestri dengan pola pengelolaan yang tepat diharapkan mampu meningkatkan produktivitas lahan yang dimiliki. Petani agroforestri merupakan sektor yang cukup rentan terhadap berbagai gejala alam seperti perubahan musim, cuaca, dan bencana alam. namun, berhasil atau tidaknya suatu lahan pertanian merupakan hal yang tidak pasti karena berbagai faktor gejala alam yang mempengaruhinya tersebut. Permasalahan gejala alam turut dipengaruhi oleh kesalahan dalam penggunaan lahan. Penerapan 
cara pengelolaan yang keliru akan menyebabkan terjadinya erosi dan tanah longsor. Dassir, dkk (2017) menjelaskan bahwa sebagian besar Petani yang bermukim di sekitar hutan yang merupakan Desa-Desa hutan di Sulawesi Selatan mengalami bencana kekeringan, banjir dan longsor pada tahun 2016 dan tahun 2017 sebagai dampak dari perubahan iklim. Dampak yang ditumbulkan akan berpengaruh kepada kehidupan petani, untuk itu diperlukan adanya cara dan strategi dalam mengelola lahan agroforestri sebagai sumber penghidupan masyarakat yang harus dilestarikan.

Strategi nafkah menurut Yuliandani (2011) didefinisikan sebagai cara dimana orang memenuhi kebutuhan mereka atau peningkatan hidup, namun lebih mendalam seperti yang diutarakan oleh Dharmawan (2007) strategi nafkah bukan sekedar means of living yang bermakna sebagai mata pencaharian. Pengertian strategi nafkah lebih mengacu pada pengertian livelihood strategy (strategi penghidupan) yaitu strategi membangun sistem penghidupan, cara bertahan hidup atau memperbaiki status kehidupan. Strategi nafkah dapat didekati dengan melihat modal penghidupan petani (livelihood assets). Modal tersebut dijelaskan Ellis (2000) sebagai livelihood Assets yaitu modal alam, modal fisik, modal manusia, modal finansial, dan modal sosial. Strategi nafkah yang dilakukan seseorang atau rumahtangga bergantung dengan sumber daya yang dimilikinya. strategi nafkah merujuk pada suatu aktivitas pemanfaatan sumber daya dimana sumber daya termasuk sumber daya hutan dimaknai dan digunakan untuk tujuan bertahan hidup atau tujuan peningkatan status ekonomi.

Pada saat seseorang atau suatu rumahtangga mengalami krisis atau guncangan posisi mereka akan mengalami kegoyahan, dalam hal ini mereka akan berusaha untuk bertahan dan mengembalikan ke posisi semula. Kemampuan tersebut disebut dengan kelentingan atau resiliensi. Resiliensi yang dimiliki oleh rumah tangga petani ketika menghadapi suatu krisis dapat dipahami sebagai kemampuan rumah tangga tersebut untuk kembali ke kondisi normal. Strategi nafkah yang diterapkan oleh rumahtangga akan berbeda pada saat kondisi normal dan kondisi krisis. Dalam menghadapi kondisi krisis, masyarakat mengelola lahan dituntut untuk menentukan bagaimana melakukan strategi nafkah dalam rangka mempertahankan dan meningkatkan sumber nafkah yang ada. Starategi nafkah yang dilakukan akan berpengaruh terhadap ketahanan (resiliensi) rumah tangga petani dalam menghadapi suatu kendala.

Banyaknya kendala yang dihadapi masyarakat dari faktor alam seperti banjir, kekeringan, longsor dan juga faktor lain seperti tingginya kebutuhan hidup rumahtangga merupakan hal-hal 
yang perlu di perhatikan oleh petani. Oleh karena itu, petani perlu melakukan resiliensi untuk dapat bertahan dalam kondisi sulit. Berdasarkan pemaparan tersebut maka penting untuk dikaji bagaimana bentuk dan pola agroforestri yang diterapkan masyarakat di desa-desa Sub DAS Minraleng Hulu dan bagaimana strategi nafkah yang dilakukan sehingga berpengaruh terhadap tingkat resiliensi yang dilakukan rumah tangga petani untuk bertahan dan menstabilkan posisinya dari guncangan dan krisis.

\section{METODE PENELITIAN}

\subsection{Tempat Penelitian}

Penelitian ini dilaksanakan pada wilayah Sub DAS Minraleng Hulu. Lokasi penelitian disajikan pada Gambar 1.

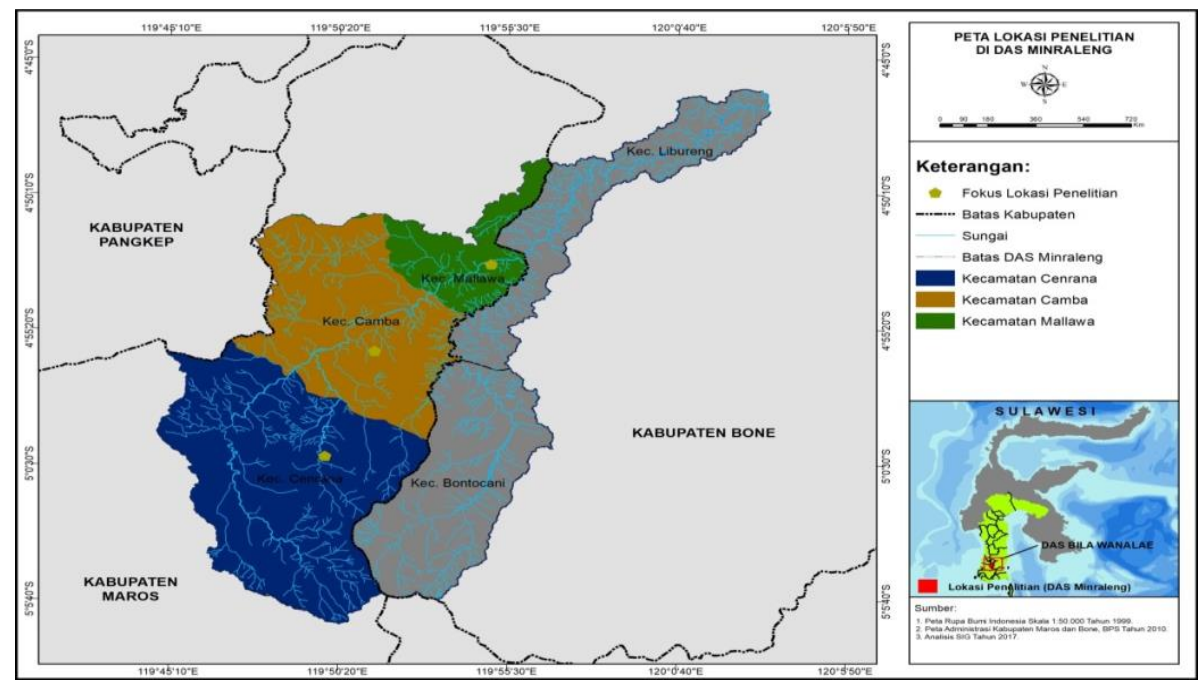

Gambar 1. Peta Lokasi Penelitian

\subsection{Metode Pengumpulan Data}

Teknik pengumpulan data dalam penelitian ini berupa :

a. Data Primer diperoleh dari survei, kuisioner dan In depth interview (wawancara mendalam) serta melakukan pengukuran dilapangan dengan melaksanakan plot ukur untuk mengetahui data vegetasi di lahan garap rumah tangga petani. Pengambilan data dilakukan dengan membuat petak ukur berukuran 20x50 meter untuk mengetahui potensi su sumber daya alam yang dimiliki rumah tangga petani yang merupakan bagian dari aset fisik dalam aset kepemilikan modal. Sampel penelitian plot ukur ditetapkan sebanyak 5 responden dari 30 responden di setiap pola 
agroforestri sehingga jumlah plot ukur sebanyak 15 plot. Data yang dikumpulkan pada setiap plot ukur, meliputi Jenis pohon, diameter, tinggi bebas cabang, tinggi total, luas bidang dasar, kerapatan jenis, kerapatan relatif dan volume pohon. Vegetasi yang di ukur adalah pohon dewasa yang berdiameter lebih dari $20 \mathrm{~cm}$. penelitian ini diasumsikan bahwa semua tanaman pertanian/perkebunan yang masuk dalam fase pohon, dikategorikan sebagai pohon. Adapun data primer selanjutnya berupa informasi kondisi biofisik, sosial ekonomi dan budaya setempat serta kendala-kendala dalam pelaksanaan kegiatan agroforestri.

b. Data sekunder diperoleh dari berbagai publikasi dan rujukan yang dikeluarkan instansi terkait yang berhubungan dengan penelitian. Obyek yang merupakan bahan pengamatan dalam penelitian ini adalah pola agroforestri yang di terapkan masyarakat di Sub Das Minraleng Hulu dan rumah tangga petani yang menjadi sampel penelitian. Data yang digunakan dalam penelitian ini berupa data kualitatif dan data kuantitif dilakukan untuk mengolah dan menganalisis data.

\subsection{Analisis Data}

a. Analisis kualitatif, Analisis kualitatif-deskriptif digunakan untuk mengkaji sistem pengelolaan agroforestri, orientasi usaha, jenis dan keragaman kombinasi pola agroforestri. Selain itu, analisis deskriptif digunakan untuk menggambarkan karakteristik responden, kepemilikan modal aset rumah tangga petani dan strategi nafkah dianalisis secara deskriptif untuk melihat strategi nafkah yang diterapkan oleh rumah tangga petani, yang dikategorikan menjadi tiga tipe yaitu strategi rekayasa sumber nafkah, strategi pola nafkah ganda, dan strategi migrasi.

\section{b. Analisis Kuantitatif}

Analisis kuantitatif terdiri atas Analisis Vegetasi yang dilakukan pengukuran luas bidang dasar dan volume pohon diakarenakan tujuan pengukuran dilakukan untuk memastikan adanya potensi asset nafkah dari modal alam yang dijelaskan responden dalam wawancara penelitian. Pengukuran parameter-parameter vegetasi pada analisis vegetasi dinilai berdasarkan analisa berikut :

1) Luas bidang dasar

Luas bidang dasar hutan (lbds) per hektar merupakan penampang melintang dari diameter batang setinggi dada (1,3 $\mathrm{m}$ dari permukaan tanah). Besarnya luas bidang dasar individu (lbd) pohon dihitung dengan rumus : 
$l b d s=0.25 \times \pi \times d b h^{2}$

Dimana :

Lbds = luas bidang dasar individu pohon $\left(\mathrm{m}^{2}\right)$

$\pi \quad=$ konstanta $(3,14)$

$\mathrm{dbh}=$ diameter batang (1,3 $\mathrm{m}$ dari permukaan tanah)

2) Volume Pohon

Volume pohon dihitung menggunakan rumus :

$$
V=l b d s x t x f
$$

Dimana :

$\mathrm{V} \quad=$ volume pohon bebas cabang $\left(\mathrm{m}^{3}\right)$

lbds = luas bidang dasar individu pohon $\left(\underline{\mathrm{m}^{2}}\right)$

$\mathrm{t} \quad=$ tinggi pohon bebas cabang $(\mathrm{m})$

$\mathrm{f} \quad=$ faktor bentuk (ditetapkan 0,7)

3) Analisis Pendapatan

Analisis ini untuk mengetahui tingkat pendapatan petani agroforestri yang diperoleh dari Perhitungan potensi penerimaan dari sumber daya alam (pohon) yang dimiliki menggunakan rumus:

Potensi penerimaan $=\mathrm{V} \times$ Harga kayu $/ \mathrm{m}^{3}$

Dimana :

$\mathrm{V}=$ volume pohon

Harga kayu $/ \mathrm{m}^{3}=$ harga kayu dipasar lokal $/ \mathrm{m}^{3}$

4) Analisis Kerapatan

a). Kerapatan Jenis i atau K (i)

$K M(i): \frac{\sum \text { individu suatu jenis (i) }}{\sum \text { Total luas areal yang digunakan untuk penarikan contoh }}$

2) Kerapatan Relatif Jenis i atau KR (i)

$K R(i): \frac{\text { Kerapatan mutlak jenis (i) } \times 100 \%}{\text { Kerapatan total seluruh jenis yang telah terambil dalam penarikan contoh }}$

b). Analisis Kepemilikan modal (livelihood assets), Instrumen kepemilikan modal rumah tangga petani merupakan hasil konstrak yang diadopsi dari Ellis (2000). Instrumen kepemilikan modal 
dilakukan menggunakan koesioner yang terdiri dari 22 pertanyaan dengan variabel modal alam, modal sosial, modal manusia, modal fisik, dan modal finansial. Kepemilikan modal keluarga diukur dengan menggunakan skala likert 1-3 dengan berbagai kriteria kategori/skala penilaian.

c). Analisis Strategi Nafkah Petani, Strategi nafkah petani agroforestri dianalisis dengan menggunakan hasil konstrak yang diadopsi dari konsep strategi nafkah menurut Scoone (1998) yang terdiri dari tiga jenis strategi nafkah, yaitu rekayasa sumber nafkah, pola nafkah ganda, dan migrasi. Variabel strategi nafkah diukur dengan skala likert 0-1 dengan kriteria ( $1=Y a, 0=$ Tidak).

d). Analisis Regresi linier berganda, Uji statistik yang digunakan yakni Uji beda independent Sample T-Test atau Uji T, Uji F digunakan untuk melihat perbedaan karakteristik responden, ekonomi, modal aset, dan strategi nafkah rumah tangga petani menurut wilayah yang berbeda (pola agroforestri).

e). Analisis Tingkat resiliensi pada berbagai pola agroforestri dianalisis berdasarkan hasil analisis deskriptif dan kualitatif dapat dirumuskan sebagai tingkat resiliensi yang dimiliki petani pada berbagai pola agroforestri di Sub DAS Minraleng Hulu Kabupaten Maros.

\section{HASIL DAN PEMBAHASAN}

\subsection{Pola Agroforestri}

\subsubsection{Pola Agroforestri Dominan Jati, Desa Batu Putih Kecamatan Mallawa.}

Desa Batu Putih merupakan wilayah yang menerapkan pola agroforestri dalam pemanfaatan lahan utamanya dalam pemanfaatan pengusahaan kayu jati. Kayu jati (Tectona grandis) sudah menjadi salah satu komoditi utama petani di Kecamatan Mallawa sejak tahun 1980. Pola yang diterapkan dibedakan atas susunan komponen ruang tanaman pertanian jangka pendek yang dipadukan dengan beberapa tanaman kehutanan jangka panjang sehingga membentuk suatu pola agroforestri yang didominasi oleh tanaman jati. Berdasarkan hasil pengamatan, pohon jati yang dimiliki petani cukup produktif, dimana jati terkesan dikelola dengan baik oleh masyarakat terlihat dengan adanya perlakuan silvikultur yang diberikan, seperti kegiatan peremajaan dan pemeliharaan.

Hasil wawancara responden menyatakan sebagian besar petani memiliki struktur pendapatan yang dapat menunjang penghidupan rumahtangga mereka dari hasil menjual pohon jati untuk dikelola sebagai kayu konstruksi. Umumya jati dalam pola ini berumur sekitar 10-40 tahun dan 
memiliki wilayah lahan yang cukup luas. Pola tanam yang dikembangkan petani dengan menggunakan bentuk random mixture, dimana jati dijadikan sebagai tanaman utama, sedangkan tanaman semusim seperti pepaya atau jagung ditanam di sela-sela tanaman dengan pola tidak beraturan.

Pola ini diterapkan petani dengan jarak tanam $5 \times 7 \mathrm{~m}, 7 \times 7 \mathrm{~m}$ sampai $8 \times 10 \mathrm{~m}$ dengan sistem agroforestri sederhana, dimana perpaduan tanaman ini dikelola dengan bentuk agrisilviculture dengan mengkombinasikan antara tanaman kehutanan berupa jati dengan tanaman semusim seperti jagung, pisang, papaya, kakao, jahe. Terbentuknya pola tanam tersebut dipengaruhi oleh tidak adanya perencanaan petani sebelumnya dalam menata letak tanaman yang dimiliki. Pengembangan agroforestri berbasis kayu dipilih petani didorong oleh permintaan kayu yang masih cukup baik sehingga sebagian petani masih memilih mengelola lahan dengan fokus utama mengelola tanaman tahunan (kayu).

Salah satu bentuk pengembangan pola agroforestri dominan jati yang diterapkan di Desa Batu Putih Kecamatan Mallawa, adalah pola agrisilvikultur dominan coklat dimana coklat/kakao sudah cukup lama digeluti oleh petani. Adapun pola tanam yang dikembangkan petani dengan menggunakan bentuk pola acak random mixture, dimana tanaman kakao dan tanaman kehutanan ditanam dengan tidak beraturan.

Terbentuknya pola tersebut dipengaruhi oleh tidak adanya perencanaan petani pola agroforestri dominan kemiri dalam menata letak tanaman yang dimiliki. Beragam sistem agroforestri dilakukan petani untuk memaksimalkan lahan yang dimiliki dengan harapan mendapatkan keuntungan yang lebih besar dari tahun-tahun sebelumnya.

\subsubsection{Pola Agroforestri Dominan Kemiri, Desa Timpuseng Kecamatan Camba.}

Masyarakat Desa Timpuseng sebagian besar bermata pencaharian utama sebagai petani. Pola Agroforestri yang berkembang di wilayah ini adalah pola agroforestri dominan kemiri, dimana dominansi tanaman kemiri tumbuh dengan subur dimulai dari perbatasan-perbatasan yang mengapit Kecamatan Camba. Pengusahaan kemiri (Aleurites moluccana) sudah menjadi salah satu pilihan utama masyarakat Kecamatan Camba sejak dahulu. Pola ini dibedakan atas susunan komponen ruang tanaman pertanian jangka pendek yang dipadukan dengan beberapa tanaman 
kehutanan jangka Panjang.Pola agroforestri ini didominasi pohon kemiri dengan jarak tanam yang beragam, yaitu $5 \times 5 \mathrm{~m}, 5 \times 7 \mathrm{~m}, 7 \times 7 \mathrm{~m}$ sampai $8 \times 10 \mathrm{~m}$.

Pola agroforestri dominan kemiri diterapkan dengan sistem agroforestri sederhana, dimana perpaduan tanaman ini dikelola dengan pola agrisilvicultture. Umumya kemiri dalam kondisi ini berumur sekitar 30-50 tahun dan memiliki wilayah lahan yang cukup luas. Dalam suatu unit manajemen lahan, pola agroforestri dominan kemiri diterapkan hampir di seluruh kepemilikan lahan responden, dimana pengelolaan lahan dikombinasikan dengan tanaman perkebunan lainnya seperti jagung, cabai dan jahe yang dikelola secara bersamaan. Selain itu tanaman kemiri dimanfaatkan untuk mengambil potensi pohon berupa biji kemiri yang dikumpulkan dan diolah lebih lanjut untuk dijual serta dapat dijadiakan sebagai asset untuk jangka panjang yang terkadang dijual perpohon untuk mendapatkan uang tunai jika sewaktu-waktu membutuhkan dana.

Pola ini dikelola dengan bentuk penggunaan lahan Trees Along Border (TAB) dimana tanaman kemiri ditanam pada bagian pinggir lahan dan tanaman pertanian berupa jahe ataupun cabai berada dibagian tengah lahan. Tingginya konsentrasi petani di sektor pertanian dipengaruhi oleh tanaman kemiri dirasakan mengalami penurunan kualitas yang ditunjukkan oleh makin rendahnya produksi dan struktur umur yang umur yang tua sehingga banyak petani mengkonversi lahan kemiri yang dimiliki menjadi lahan pertanian. Pada beberapa lahan kepemilikan petani, sistem agrisilvikultur juga diterapkan dalam bentuk random mixture, dimana tanaman pertanian dan tanaman kehutanan diletakkan dengan pola yang tidak beraturan.

Tanaman kemiri ditanam dengan tidak beraturan yang diikuti oleh tanaman penaung seperti merica dan ubi kayu yang berada disekitarnya. Model pengelolaan ini dilakukan petani agar dapat meningkatkan produktivitas lahan yang dimiliki sekaligus dapat memberikan pendapatan yang lebih dari hasil pengusahaan lahan.

\subsubsection{Pola Agroforestri Dominan Akasia, Desa Cenrana Baru Kecamatan Cenrana.}

Masyarakat Desa Cenrana Baru sebagian besar bermata pencaharian utama sebagai petani. Pola Agroforestri yang berkembang di Desa cenrana Baru adalah pola agroforestri dominan akasia, dimana dominansi tanman kemiri tumbuh dengan subur di berbagai wilayah perkebunan petani. Disamping pengelolaan tanaman akasia, Desa Cenrana Baru memiliki banyak potensi tanaman tahunan yang dikembangkan, seperti tanaman mahoni, tanaman kemiri, tanaman mangga dan 
tanaman jati namun pada umumnya tanaman akasia merupakan tanaman yang paling mendominasi tutupan lahan di Desa Cenrana Baru.

Pengusahaan akasia (Acacia aucaliformis) menjadi salah satu pilihan utama masyarakat karena memiliki sifat yang dapat tumbuh dengan cepat serta dapat tumbuh dan berkembang pada konidisi yang cukup ekstrim. Pola ini dibedakan atas susunan komponen ruang tanaman pertanian jangka pendek yang dipadukan dengan beberapa tanaman kehutanan jangka panjang. Adapun perpaduan tanaman yang dikelola masyarakat seperti kopi, kacang, kacang tanah dan jagung.

Pola agroforestri ini didominasi pohon akasia umumnya dikelola dengan jarak tanam yang beragam, yaitu $5 \times 5 \mathrm{~m}, 5 \times 7 \mathrm{~m}$, sampai $7 \times 7 \mathrm{~m}$. Pola agroforestri dominan kemiri diterapkan dengan sistem agroforestri sederhana, dimana perpaduan tanaman ini dikelola dengan pola agrisilviculture. Pengelolaan lahan kemiri dengan sistem agrisilviculture ditandai dengan komposisi lahan berisi tanaman kehutanan berupa akasia yang ditanam secara tumpang sari dengan tanaman kopi. Tanaman akasia dikelola dengan tanaman kopi secara bersamaan. Adapun bentuk pengelolaan tanaman kopi ditanam secara merata bersebelahan dengan tanaman akasia. Berdasarkan hasil pengamatan, tanaman kopi merupakan jenis tanaman yang cocok dikombinasikan dengan tanaman akasia. Tanaman akasia dijadikan sebagai tanaman penaung untuk tanaman kopi pada masa pertumbuhannya. Kombinasi tanaman ini dilakukan petani untuk memaksimalkan lahan yang dimiliki.

Pada berbagai kepemilikan lahan petani agroforestri dominan kemiri secara umum menerapkan konsep pola agrisilvikultur namun yang membedakan adalah pada pola tanam yang dikehendaki. seperti yang terlihat pada Gambar 2.

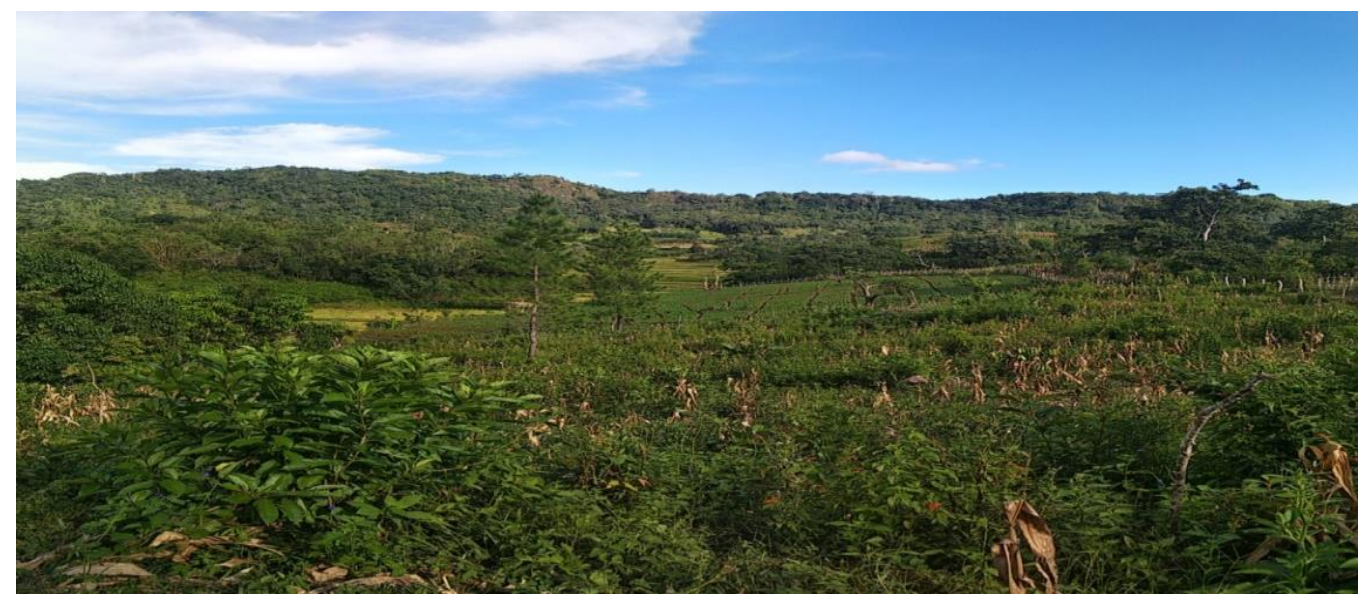

Gambar 2. Pola agroforestri Dominan Akasia Dengan Pola Acak 
Gambar 2 memperlihatkan petani menggunakan pola tanam secara acak (kebun campuran) secara tidak beraturan. Tanaman akasia dan tanaman budidaya pertanian seperti tanaman jagung, kacang tanah ditanam pada lahan yang sama secara bersamaan. Pada kondisi diatas dapat diketahui tahapan perkembangan agroforestri dominan kemiri pada masa permudaan ditanam secara bersamaan dengan tanaman budidaya pertanian seperti kacang dan jagung. Pada umumnya setelah tanaman akasia berumur 3 tahun, maka petani akan berpindah lahan dalam mengelola tanaman budidaya pertanian sehingga akasia dapat tumbuh secara dominan pada wilayah tersebut. Hal ini merupakan cara masyarakat dalam manajemen pengkombinasian tanaman kehutanan dan pertanian untuk mendapatkan hasil yang mereka inginkan.

\subsection{Modal Aset (Livelyhood Assets)}

Petani agroforestri di berbagai pola agroforestri secara keseluruhan memanfaatkan kelima modal aset nafkah yang mereka miliki. Tingkat kepemilikan modal tersebut digunakan dengan cara berbeda satu dengan yang lainnya. Namun rumah tangga berusaha memainkan kelima modal nafkah tersebut secara maksimal untuk mendapatkan pendapatan sehingga rumah tangga dapat bertahan hidup. Pemanfaatan modal tersebut diwujudkan dalam strategi nafkah yang diterapkan rumah tangga, modal nafkah berhubungan dengan strategi nafkah apa yang akan dilakukan rumahtangga.

Tingkat kepemilikan aset modal petani pola agroforestri dominan jati yang memiliki aset nafkah tertinggi adalah modal fisik sebesar $73.6 \%$ dan terendah adalah modal finansial sebesar $59,4 \%$. Penguatan modal fisik dipengaruhi oleh tingginya potensi sumber daya hutan (pohon) yang dimiliki oleh petani. Potensi hutan seringkali dijadikan petani sebagai pendapatan sekaligus sebagai sumber modal untuk mengelola lahan lain yang dimiliki. Modal finansial sebagai modal aset terendah dipengaruhi oleh rendahnya aspek pendapatan dan tingkat kemampuan menabung. Aspek pendapatan dan tingkat kemampuan menabung yang dimiliki kurang mencukupi untuk memilih strategi-strategi pengelolaan lahan yang baik sehingga potensi lahan yang dimiliki tidak dapat dimanfaatkan secara maksimal.

Tingkat kepemilikan aset modal petani pola agroforestri dominan kemiri yang memiliki aset nafkah tertinggi adalah modal fisik sebesar $89,16 \%$ dan aset modal terendah adalah modal sosial sebesar $63,3 \%$. Penguatan modal fisik dipengaruhi oleh potensi sumber daya hutan dan 
kepemilikan sarana produksi. Kepemilikan potensi sumber daya hutan yang dimiliki yang dapat dijadikan sebagai pendapatan sekaligus sebagai sumber modal untuk mengelola lahan lain sedangkan dalam hal kepemilikan sarana produksi sangat membantu petani dalam mengelola lahan secara efektif dan efisien. Modal sosial sebagai modal aset terendah dipengaruhi oleh rasa saling percaya dan resiprositas (hubungan timbal balik) yang rendah. Dalam mengelola lahan petani lebih sering mengelola lahan secara sendiri-sendiri atau berkelompok dengan memanfaatkan tenaga kerja harian dibandingkan dengan memanfaatkan kerjasama antar sesama petani. Kurangnya kerjasama antar sesama petani dipengaruhi oleh kurang eratnya hubungan antar petani dan rasa saling percaya dalam mengelola lahan secara bersama-sama.

Tingkat kepemilikan aset modal petani pola agroforestri dominan akasia yang memiliki aset nafkah tertinggi adalah modal sosial sebesar $86,67 \%$ dan terendah adalah modal finansial dengan persentase $56,1 \%$. Penguatan modal sosial dipengaruhi oleh norma sosial dan rasa saling percaya. Adanya pemahaman dan bentuk-bentuk perilaku yang tumbuh dalam masyarakat sangat membantu petani dalam mengelola lahan agroforestri yang dimiliki. Modal finansial sebagai modal terendah dipengaruhi oleh kemampuan menabung. Rendahnya kemampuan menabung didasari dari luas lahan garap pertanian yang sempit, membuat petani tidak mendapatkan penghasilan yang cukup untuk disisihkan secara rutin. Kondisi ini diperparah oleh kurangnya pendapatan yang diterima dari sektor non pertanian membuat kemamuan menabung petani ikut rendah. Berdasarkan hasil pengamatan terhadap keseluruhan aspek pada masing-masing modal, maka dapat disimpulkan pula bahwa perlu adanya perbaikan-perbaikan terhadap beberapa aspek yang mempengaruhi nilai pada masing-masing modal untuk menciptakan keseimbangan terhadap masing-masing modal yang bertujuan untuk menciptakan pengembangan agroforestri yang berkelanjutan. Dengan demikian, semakin tinggi modal asset modal yang dimiliki maka akan berpengaruh pada tingkat resiliensi petani dalam menghadapi kondisi-kondisi krisis yang akan terjadi dan mampu memudahkan dalam menerapkan strategi-strategi dalam meningkatkan pendapatan rumah tangga petani.

\subsection{Strategi Nafkah (Livelyhood Stategy)}

\subsubsection{Strategi Nafkah Pola Agroforestri Dominan Jati}


Berdasarkan hasil analisis strategi nafkah (livelihood strategy), diketahui pola agroforestri dominan jati memiliki tingkat strategi nafkah yang beragam. Hasil sebaran strategi nafkah pola agroforestri dominan jatii memperlihatkan bahwa rekayasa sumber nafkah paling banyak dilakukan oleh petani adalah pemberantasan hama dan penyakit dan memperbaiki cara produksi. Diversifikasi mata pencaharian atau pola nafkah ganda yang paling banyak dilakukan adalah optimalisasi tenaga kerja. Sedangkan pada strategi rekayasa spasial atau migrasi petani melakukan migrasi sirkuler dengan bekerja di luar daerah sebagai buruh kerja disebuah perusahaan di Ibu kota kabupaten/ Ibu Kota Provinsi.

\subsubsection{Strategi Nafkah Pola Agroforestri Dominan Kemiri}

Hasil sebaran strategi nafkah menunjukkan mayoritas responden memiliki respon yang tinggi terhadap aktivitas rekayasa sumber nafkah. Dalam diversifikasi mata pencaharian, aktifitas yang paling sering dilakukan adalah menjalin hubungan kerjasama (patronase) sedangkan pada strategi rekayasa spasial atau migrasi petani melakukan migrasi sirkuler dengan beberapa kali meninggalkan tempat tinggal menuju lbu Kota Provinsi untuk berdagang dalam waktu yang tidak lama.

\subsubsection{Strategi Nafkah Pola Agroforestri Dominan Akasia}

Hasil sebaran strategi nafkah pola agroforestri dominan akasiai memperlihatkan jenis strategi nafkah yang diterapkan rumahtangga pada rekayasa sumber nafkah yang paling banyak dilakukan oleh petani adalah pemberantasan hama dan penyakit dan memperbaiki cara produksi. Diversifikasi mata pencaharian atau pola nafkah ganda yang paling banyak dilakukan adalah optimalisasi tenaga kerja dan penambahan waktu kerja. Pada strategi rekayasa spasial petani pola agroforestri dominan akasia melakukan migrasi sirkuler dan migrasi permanen.

\subsection{Faktor-faktor Yang Mempengaruhi Resiliensi Pada Berbgai Pola Agroforestri}

\subsubsection{Faktor Resiliensi Petani Pola Agroforestri Dominan Jati.}

Faktor-faktor yang mempengaruhi resiliensi pola agroforestry dominan jati diukur pada waktu recovery saat terjadi krisis adalah pemanfaatan sumber daya air, rasa saling percaya, resiprositas (hubungan timbal balik), keterampilan, potensi sumber daya hutan, tingkat kemampuan menabung dan akses terhadap pinjaman. Hasil uji regresi (uji T) menunjukkan aset modal petani berupa 
pemanfaatan sumber daya air, Rasa saling percaya, resiprositas (hubungan timbal balik), keterampilan, potensi sumber daya hutan, tingkat kemampuan menabung dan akses terhadap pinjaman memiliki nilai signifikasi $<0,1$ dan $T$ hitung $>\mathrm{T}$ tabel $(1,8331)$ yang berarti memiliki pengaruh signifikan secara parsial atau sendiri-sendiri terhadap resiliensi pada waktu recovery saat terjadi krisis rumah tangga petani. Hasil uji regresi (uji F) menunjukkan keseluruhan aset modal petani memiliki nilai signifikasi $>0,1$ dan nilai $F$ hitung $<F$ tabel (3.1503) yang berarti keseluruhan aset modal petani tidak memiliki pengaruh yang signifikan secara simultan atau bersama-sama terhadap resiliensi pada waktu recovery saat terjadi krisis rumah tangga petani.

Faktor-faktor yang mempengaruhi resiliensi pola agroforestey dominan jati diukur pada tingkat adaptasi saat terjadi krisis adalah tingkat kemampuan menabung. Hasil uji regresi (uji T) menunjukkan aset modal petani berupa tingkat kemampuan menabung memiliki nilai signifikasi < 0,1 dan $T$ hitung $>T$ tabel $(1,8331)$ yang berarti memiliki pengaruh signifikan secara parsial atau sendiri-sendiri terhadap resiliensi pada tingkat adaptasi saat terjadi krisis rumah tangga petani. Hasil uji regresi (uji F) menunjukkan keseluruhan aset modal petani memiliki nilai signifikasi > 0,1 dan nilai $F$ hitung $<F$ tabel (3.1503) yang berarti keseluruhan aset modal petani tidak memiliki pengaruh yang signifikan secara simultan atau bersama-sama terhadap resiliensi pada tingkat adaptasi saat terjadi krisis rumah tangga petani.

\subsubsection{Faktor Resiliensi Petani Pola Agroforestri Dominan Kemiri.}

Faktor-faktor yang mempengaruhi resiliensi pola agroforestey dominan kemiri diukur pada tingkat adaptasi adalah variabel jaringan sosial, jarak lahan dari pemukiman dan pendapatan memiliki pengaruh yang signifikan terhadap resiliensi petani. Hasil uji regresi (uji T) menunjukkan aset modal petani berupa jaringan sosial, ketersediaan prasarana jalan dan pendapatan memiliki nilai signifikasi $<0,1$ dan $T$ hitung $>\mathrm{T}$ tabel $(1,8331)$ yang berarti memiliki pengaruh signifikan secara parsial atau sendiri-sendiri terhadap resiliensi pada tingkat adaptasi saat terjadi krisis rumah tangga petani. Hasil uji regresi (uji F) menunjukkan keseluruhan aset modal petani memiliki nilai signifikasi $>0,1$ dan nilai $F$ hitung $<F$ tabel (3.1503) yang berarti keseluruhan aset modal petani tidak memiliki pengaruh yang signifikan secara simultan atau bersama-sama terhadap resiliensi pada tingkat adaptasi saat terjadi krisis rumah tangga petani. 


\subsubsection{Faktor Resiliensi Petani Pola Agroforestri Dominan Akasia.}

Hasil uji regresi (uji F) menunjukkan keseluruhan aset modal petani memiliki nilai signifikasi < 0,1 dan nilai $\mathrm{F}$ hitung $>\mathrm{F}$ tabel (3.1503) yang berarti keseluruhan aset modal petani memiliki pengaruh yang signifikan secara simultan atau bersama-sama terhadap resiliensi pada waktu recovery saat terjadi krisis rumah tangga petani.

Faktor-faktor yang mempengaruhi resiliensi pola agroforestey dominan akasia diukur pada tingkat adaptasi saat terjadi krisis adalah tingkat penguasaan lahan, rasa saling percaya, keterampilan dan akses terhadap pinjaman. Hasil uji regresi (uji T) menunjukkan aset modal petani berupa pemanfaatan iklim, norma sosial, tenaga kerja keluarga, jumlah tanggungan dan akses terhadap pinjaman memiliki nilai signifikasi $<0,1$ dan $T$ hitung $>T$ tabel $(1,8331)$ yang berarti memiliki pengaruh signifikan secara parsial atau sendiri-sendiri terhadap resiliensi pada tingkat adaptasi saat terjadi krisis rumah tangga petani. Hasil uji regresi (uji F) menunjukkan keseluruhan aset modal petani memiliki nilai signifikasi $>0,1$ dan nilai $F$ hitung $<F$ tabel (3.1503) yang berarti keseluruhan aset modal petani tidak memiliki pengaruh yang signifikan secara simultan atau bersama-sama terhadap resiliensi pada tingkat adaptasi saat terjadi krisis rumah tangga petani.

\subsection{Tingkat Resiliensi Pada Berbgai Pola Agroforestri}

Tingkat resiliensi petani pada berbagai pola agroforestri yang dihitung secara keseluruhan dari hasil penggabungan nilai responden dari perhitungan yang ditinjau dari kepemilikan asset modal, bentuk strategi nafkah dan ditinjau dari resiliensi petani. Tingkat resiliensi pada berbagai pola agroforestri dapat dilihat pada Tabel 1

Tabel 1. Tingkat Resiliensi Petani Pola Agroforestri

\begin{tabular}{cccccc}
\hline No & Pola Agroforestri & $\begin{array}{l}\text { Aset } \\
\text { Modal }\end{array}$ & $\begin{array}{c}\text { Strategi } \\
\text { Nafkah }\end{array}$ & Resiliensi & $\begin{array}{c}\text { Skor } \\
\text { Total }\end{array}$ \\
\hline 1 & Agroforestri Dominan Jati & 1274 & 219 & 141 & 1634 \\
2 & Agroforestri Dominan Kemiri & 1349 & 414 & 207 & 1970 \\
3 & Agroforestri Dominan Akasia & 1355 & 369 & 120 & 1844 \\
\hline
\end{tabular}

Berdasarkan Tabel di atas, diketahui bahwa tingkat resiliensi ditinjau dari kepemilikan aset modal (modal alam, modal sosial, modal manusia, modal fisik dan modal finansial), ditinjau dari bentuk strategi nafkah petani (rekayasa sumber nafkah, diversifikasi mata pencaharian dan pola migrasi) serta ditinjau dari resiliensi (waktu recovery saat kritis dan tingkat penyesuaian/adaptasi 
saat kritis), maka dapat diketahui bahwa tingkat resiliensi tertinggi pada petani pola agroforestri dominan kemiri dengan skor 1970, adapun tingkat resiliensi sedang pada pola agroforestri dominan akasia sengan skor total 1844 dan tingkat resiliensi terendah pada petani pola agroforestri dominan jati dengan total skor 1634 .

Nilai skor di atas merupakan ukuran tingkat resiliensi yang dimiliki petani pada berbagai pola agroforestri di Sub DAS Minraleng Hulu Kabupaten Maros. Semakin tinggi nilai resiliensi menandakan bahwa kemampuan petani dalam mengelola lahan semakin baik sehingga dapat berpengaruh pada kualitas dan kuantitas lahan agroforestri yang dimiliki. Kualitas dan kuantitas lahan agroforestri tersebut akan menciptakan keuntungan dari segi ekonomi maupun dari segi ekologi. Pengembangan lahan agroforestri yang didukung oleh kepemilikan aset dan strategi dalam mengelola lahan secara tidak langsung akan memperbaiki fungsi ekosistem yang ada disekitarnya, utamanya pada ekosistem Sub DAS Minraleng Hulu Kabupaten Maros sehingga sehingga dampak-dampak buruk dari kerusakan alam dapat dijegah melalui pengelolaan lahan yang baik. Semua rumahtangga berbagai pola agroforestri merupakan merupakan rumahtangga yang mempunyai kemampuan untuk bertahan hidup jika dilanda krisis atau guncangan ekonomi.

Hal ini disebabkan oleh rumahtangga tidak hanya mempunyai sumber pendapatan dari satu sektor saja, umumnya mereka menerapkan strategi pola nafkah ganda. Berdasarkan tingkat resiliensi yang dilihat dari lamanya waktu yang diperlukan rumahtangga dari total 90 respenden untuk kembali ke posisi normal ada 17 rumahtangga yang tingkat resiliensinya rendah, sedangkan 18 rumahtangga menunjukkan tingkat resiliensi tinggi dan sisanya 55 responden menunjukkan tingkat resiliensi sedang. Hubungan antara tingkat resiliensi dan masing-masing tingkat kepemilikan modal menyatakan hubungan yang memiliki pengaruh pada masing-masing aspek faktor-faktor pembatas yaitu faktor-faktor aset modal yang dimiliki. Resiliensi juga dipengaruhi oleh tingkat pendapatan. Pendapatan akan mempengaruhi rumahtangga untuk bisa bertahan dari ancaman krisis. Semakin tinggi pendapatan rumahtangga maka semakin tinggi pula kemampuan mereka untuk bertahan hidup. Pendapatan yang tinggi memungkinkan rumahtangga untuk mempunyai kemampuan menabung yang tinggi. 


\section{KESIMPULAN}

Pengembangan pola agroforestri yang dilakukan petani pada pola agroforestri dominan jati dikelola dengan bentuk agrisilviculture dengan pola tanam beraturan dan tidak beraturan, dominan coklat dengan pola tanam yang tidak beraturan. Untuk pola agroforestri dominan kemiri dikelola dengan bentuk pola ruang dan pola acak (tidak beraturan) sedangkan pada pola agroforestri dominan akasia dikelola dengan pola tanam pola tanam beraturan dan tidak beraturan.

Faktor-faktor yang mempengaruhi resiliensi pada pola agroforestri dominan jati ditinjau adalah variabel pemanfaatan sumber daya air, rasa saling percaya, resiprositas, keterampilan, potensi sumber daya hutan, tingkat kemampuan menabung dan akses terhadap pinjaman. Sedangkan pada pola kemiri adalah variabel jaringan sosial, potensi sumber daya hutan, jarak lahan dari pemukiman, tingkat aksesibilitas lahan, pendapatan, tingkat kemampuan menabung dan jaringan sosial. Untuk pola agroforestri dominan akasia ditinjau dari waktu recovery dan bentuk adaptasi saat kritis adalah variabel norma sosial, jaringan sosial, tenaga kerja keluarga, jumlah tanggungan, akses terhadap sumber daya lahan, pemanfaatan iklim, serta akses terhadap pinjaman. Tingkat resiliensi yang memiliki nilai tertinggi adalah petani pola agroforestri dominan kemiri dengan skor total 1970, tingkat resiliensi sedang adalah pola agroforestri dominan jati dengan total skor 1844 dan tingkat agroforestri terendah pada pola agroforestri dominan jati dengan total skor 1634 .

\section{DAFTAR PUSTAKA}

Dassir. M. Sadapotto, A. dan Samuel A.P. 2017. Peningkatan Kapasitas Adaptasi dan Resiliensi Livelihood Petani Hutan terhadap Resiko Bencana Perubahan Iklim Di Areal TN BABUL Sulawesi Selatan. Laporan Penelitian PUPT, LP2M Unhas (Tidak Dipublikasikan).

Dharmawan AH. 2007. Sistem penghidupan dan nafkah pedesaan pandangan sosiologi nafkah (livelihood sociology) mazhab barat dan mazhab bogor. Sodality jurnal transdisiplin sosiologi, komunikasi dan ekologi manusia. 01 (02); 169-192.

Ellis F. 2000. Rural Livelihood and Diversity in Developing Countries. London (UK): Oxford University Press.

Yuliandani R. 2011. Analisis struktur nafkah dan peghidupan rumahtangga pekerja batik tulis tradisional (studi sosio-ekonomi dua tipe industri batik di Kota Pekalongan Provinsi Jawa Tengah) [skripsi]. Bogor (ID): Institut Pertanian Bogor 